(c) American Dairy Science Association, 2003.

\title{
Effects of Feeding Dairy Cows Protein Supplements of Varying Ruminal Degradability ${ }^{1}$
}

\author{
S. M. Reynal* and G. A. Broderick† \\ ${ }^{*}$ Department of Dairy Science, University of Wisconsin \\ †Agricultural Research Service, USDA \\ US Dairy Forage Research Center, Madison, WI
}

\section{ABSTRACT}

Twenty-five (10 ruminally cannulated) Holstein cows averaging $82 \pm 34 \mathrm{~d}$ in milk were assigned to $5 \times 5$ Latin squares (21-d periods) and fed diets supplemented with one of four different proteins to assess effects on production, ruminal metabolism, omasal flow of $\mathrm{N}$ fractions, and degradation rates of protein supplements. Total mixed diets contained (dry matter basis) $44 \%$ corn silage, $22 \%$ alfalfa silage, $2 \%$ urea, and $31 \%$ concentrate. Five concentrate mixes were fed: $31 \%$ high-moisture shelled corn (HMSC; basal); 9\% solvent soybean meal (SSBM), 22\% HMSC; $10 \%$ expeller soybean meal (ESBM), 21\% HMSC; $5.5 \%$ blood meal (BM), 25.5\% HMSC; and 7\% corn gluten meal (CGM), 24\% HMSC. Diets averaged, respectively, 15.8, 19.1, 19.7, 20.3, and $19.3 \%$ crude protein. Feeding the basal diet reduced intake and yield of milk, fat-corrected milk (FCM), and all milk components compared to the protein-supplemented diets. Milk yield was higher for cows fed ESBM and CGM, fat yield was higher for cows fed SSBM and CGM, but FCM and protein yields were not different among cows fed supplemental protein. Based on omasal sampling, mean in vivo estimates of ruminal degradation rate for the crude protein in SSBM, ESBM, BM, and CGM was, respectively, 0.417, 0.179, 0.098, and $0.051 / \mathrm{h}$ (computed using passage rates observed for the small particle phase; mean $=0.14 / \mathrm{h}$ ), and $0.179,0.077$, 0.042 , and $0.026 / \mathrm{h}$ (computed using a passage rate of $0.06 / \mathrm{h}$ ). The in vivo degradation rate computed for SSBM at a passage rate $=0.06 / \mathrm{h}$ was similar to that estimated using the inhibitor in vitro method. However, in vivo degradation rates computed at passage rate $=$ 0.06/h for ESBM, BM, and CGM were about two, four, and three times more rapid than those estimated by

\footnotetext{
Received June 14, 2002.

Accepted October 14, 2002.

Corresponding author: G. A. Broderick; e-mail: glenb@dfrc. wisc.edu.

${ }^{1}$ Mention of any trademark or proprietary product in this paper does not constitute a guarantee or warranty of the product by the USDA or the Agricultural Research Service and does not imply its approval to the exclusion of other products that also may be suitable.
}

inhibitor in vitro. Experimental proteins fed in this trial will be used as standards for developing in vitro methods for predicting rates of ruminal protein degradation. (Key words: dairy cow, protein supplementation, in vivo degradation rate)

\begin{abstract}
Abbreviation key: $\mathbf{B M}=$ Blood meal, $\mathbf{C G M}=$ corn gluten meal, ESBM = expeller soybean meal, HMSC = rolled high-moisture shelled corn, IIV $=$ inhibitor in vitro method, OTD = omasal true digesta, $\mathbf{S S B M}=$ solvent soybean meal, TAAN = total amino acid $\mathrm{N}$.
\end{abstract}

\section{INTRODUCTION}

Optimizing the balance between microbial protein synthesis and degradation in the rumen can reduce $\mathrm{N}$ excretion and, consequently, $\mathrm{N}$ losses to the environment. New systems of ruminant ration formulation (AFRC, 1992; Sniffen et al., 1992; NRC, 2001) have incorporated more complex computations for estimating protein synthesis and degradation in the rumen. However, accurate information on the kinetics of ruminal protein degradation is required to successfully apply these systems. Lack of data and reliable methodology have led to the common practice of feeding extra protein to dairy cows to avoid possible amino acid shortages at the small intestine that could compromise production. Most commonly, the in situ method has been used to assess protein degradation kinetics. Although adopted by the NRC (2001), this technique is time consuming and has theoretical limitations that call its accuracy into question (Broderick, 1994). Routine in vitro methods that are both accurate and rapid are needed to allow timely characterization of protein degradation kinetics of common feeds. The inhibitor in vitro method (IIV) developed by Broderick (1987) has been applied to determine rate and extent of protein degradation. However, this technique has been validated for only a few proteins. Protein standards with known in vivo degradabilities are needed for use in development and validation of all in vitro methods.

An omasal canal sampling technique developed by Huhtanen et al. (1997) and modified by Ahvenjarvi et al. (2000) is a less invasive approach that has proven 
to be reliable for measuring nutrient flows out of the rumen. This technique, together with the continuous infusion of digesta flow markers and use of purines to quantify microbial protein, allows for the determination of rate and extent of ruminal protein degradation in vivo in cows fitted with only ruminal cannulas.

The objectives of this experiment were 1) to quantify the effects of feeding protein supplements with differing ruminal degradabilities on milk production, ruminal metabolites, and nutrient flows out of the rumen and 2 ) to estimate in vivo rates of ruminal protein degradation of four protein supplements commonly fed to dairy cows and to compare these results with those obtained using the IIV method.

\section{MATERIALS AND METHODS}

\section{Experimental Procedure}

Twenty-five (10 with ruminal cannulas) multiparous lactating Holstein cows, averaging $84(\mathrm{SD} \pm 34) \mathrm{DIM}$ and $596(\mathrm{SD} \pm 66) \mathrm{kg}$ of $\mathrm{BW}$ at the beginning of the study, were blocked by DIM into five Latin squares (two squares of cannulated cows). Cows were randomly assigned within squares to treatment TMR containing (DM basis) $43.5 \%$ rolled corn silage, $22 \%$ alfalfa silage, $2 \%$ urea, $1.5 \%$ minerals, and $31 \%$ concentrate [protein supplement plus rolled high-moisture shelled corn (HMSC)]. Diets (Table 1) differed in the proportion and source of protein supplement in the concentrate: diet A (basal), (31\% HMSC, no supplement); diet B [22\% HMSC, 9\% solvent soybean meal (SSBM)]; diet C [21\% HMSC, 10\% expeller soybean meal, (ESBM; SoyPlus, West Central Coop., Ralston, IA)]; diet D [25.5\% HMSC, $5.5 \%$ ring-dried blood meal (BM)]; and diet E [24\% HMSC, 7\% corn gluten meal (CGM)]. All cows were injected with one-half dose of bST [250 mg of Posilac (Monsanto, St. Louis, MO)] beginning on d 8 of period one of the trial and then injected with that amount of bST once each week for the remainder of the trial. This was done to avoid the effect of having unequal numbers of biweekly bST injections during alternating 3 -wk periods. Cows were housed in tie stalls and had free access to water throughout the trial. Care and handling of the experimental animals, including ruminal cannulation, was conducted as outlined in the guidelines of the University of Wisconsin institutional animal care and use committee.

Each experimental period lasted $21 \mathrm{~d}$ and consisted of a 12-d adaptation period and a 9-d sample collection period. Diets were offered once daily at $1000 \mathrm{~h}$, except for the cannulated cows during sample collection when diets were offered twice daily at 1000 and $2200 \mathrm{~h}$. Orts were collected and recorded once daily at $900 \mathrm{~h}$, and the feeding rate was adjusted daily to yield orts of about
5 to $10 \%$ of intake. Weekly composites of corn silage, alfalfa silage, HMSC, TMR, and orts were prepared from daily samples of about $0.5 \mathrm{~kg}$ that were stored at $-20^{\circ} \mathrm{C}$. Weekly samples also were taken of urea, SSBM, ESBM, BM, and CGM and stored at 21 to $24^{\circ} \mathrm{C}$. Proportions of each ration ingredient on an as-fed basis were adjusted weekly based on DM determined by drying the weekly composites of corn silage, alfalfa silage, and HMSC at $60^{\circ} \mathrm{C}(48 \mathrm{~h})$ and representative samples of urea, SSBM, ESBM, BM, and CGM at $105^{\circ} \mathrm{C}$ (AOAC, 1980). Intake of DM was computed based on the $60^{\circ} \mathrm{C}$ DM determinations for TMR and orts. After drying, ingredients and TMR were ground through a 1-mm screen (Wiley mill; Arthur H. Thomas, Philadelphia, PA). Period composites of the major diet ingredients and TMR were prepared by mixing equal amounts of DM from these dried and ground weekly composites. Body weights were measured on 3 consecutive days at the start of the trial and at the end of each period to compute BW change. Milk yield was recorded at all daily p.m. and a.m. milkings. Milk was sampled at two consecutive milkings (p.m. and a.m.) on d 13 and 20 of each period and was analyzed for fat, protein, lactose, and SNF by infrared analysis (AgSource, Menomonie, $\mathrm{WI}$ ).

The markers used to estimate digesta flows at the omasal canal in the cannulated cows (France and Siddons, 1986) were indigestible NDF for the large particle phase (Huhtanen et al., 1994), $\mathrm{YbCl}_{3}$ for the small particle phase (Siddons et al., 1985), and Co-EDTA for the fluid phase (Uden et al., 1980). The $\mathrm{YbCl}_{3}$ and Co-EDTA were dissolved in distilled water and continuously infused into the rumen for $6 \mathrm{~d}$. Digesta flowing out the rumen was collected from the omasal canal (Huhtanen et al., 1997; Ahvenjarvi et al., 2000) four times daily at 2-h intervals during 3 consecutive days to represent the 24-h feeding cycle. Each 400-ml digesta sample was divided into subsamples of 100 and $300 \mathrm{ml}$. Formaldehyde [ $1 \mathrm{ml}$ of $40 \%$ (wt/vol)] was added to the $100-\mathrm{ml}$ subsample, and both subsamples were stored at $-20^{\circ} \mathrm{C}$ as they were collected and pooled over the sampling period to yield single 1.2- and 3.6-L composites from each cow in each period. Bacteria were isolated from the 1.2-L pooled composites by differential centrifugation. The 3.6-L pooled composites were thawed at room temperature and separated into the three digesta phases that were recombined in the correct proportions to reconstitute the omasal true digesta (OTD) flowing out of the rumen based on the triple-marker method of France and Siddons (1986). A sample of whole ruminal contents was taken at $6 \mathrm{~h}$ postfeeding and squeezed through two layers of cheesecloth to yield about 1000 $\mathrm{ml}$ of strained ruminal fluid for use in isolation of protozoa. At the time of the morning feeding on $d 17$ (first 
Table 1. Composition of diets.

\begin{tabular}{|c|c|c|c|c|c|}
\hline \multirow[b]{2}{*}{ Item } & \multicolumn{5}{|c|}{ Diet } \\
\hline & $\mathrm{A}$ & B & $\mathrm{C}$ & $\mathrm{D}$ & $\mathrm{E}$ \\
\hline & \multicolumn{5}{|c|}{$(\%$ of $\mathrm{DM})$} \\
\hline \multicolumn{6}{|l|}{ Ingredients } \\
\hline Corn silage & 43.6 & 43.7 & 43.7 & 43.7 & 43.7 \\
\hline Alfalfa silage & 22.2 & 22.2 & 22.2 & 22.2 & 22.2 \\
\hline High moisture shelled corn & 30.6 & 21.7 & 20.7 & 25.2 & 23.7 \\
\hline Urea & 2.0 & 2.0 & 2.0 & 2.0 & 2.0 \\
\hline Solvent soybean meal & - & 8.8 & - & - & - \\
\hline Expeller soybean meal & _ & - & 9.7 & _ & _ \\
\hline Blood meal & - & - & - & 5.4 & - \\
\hline Corn gluten meal & _- & _- & _ & - & 6.8 \\
\hline Sodium bicarbonate & 0.5 & 0.5 & 0.5 & 0.5 & 0.5 \\
\hline Dicalcium phosphate & 0.6 & 0.6 & 0.6 & 0.6 & 0.6 \\
\hline Salt & 0.3 & 0.3 & 0.3 & 0.3 & 0.3 \\
\hline Mineral mix & 0.1 & 0.1 & 0.1 & 0.1 & 0.1 \\
\hline Vitamin-mineral concentrate ${ }^{1}$ & 0.1 & 0.1 & 0.1 & 0.1 & 0.1 \\
\hline \multicolumn{6}{|l|}{ Nutrient content of diets } \\
\hline DM, \% & 44.8 & 45.3 & 45.2 & 45.1 & 45.0 \\
\hline $\mathrm{CP}, \%$ of $\mathrm{DM}$ & 15.8 & 19.1 & 19.7 & 20.3 & 19.3 \\
\hline $\mathrm{NE}_{\mathrm{L}},{ }^{2} \mathrm{Mcal} / \mathrm{kg}$ of $\mathrm{DM}$ & 1.50 & 1.50 & 1.51 & 1.51 & 1.50 \\
\hline $\mathrm{NDF}, \%$ of DM & 27.1 & 26.9 & 27.1 & 26.9 & 26.1 \\
\hline $\mathrm{ADF}, \%$ of $\mathrm{DM}$ & 17.5 & 17.3 & 17.3 & 17.0 & 16.7 \\
\hline NPN, $3 \%$ of total N & 55.3 & 43.9 & 42.0 & 40.0 & 39.0 \\
\hline $\mathrm{NH}_{3}-\mathrm{N}, \%$ of total $\mathrm{N}$ & 4.6 & 3.8 & 3.8 & 3.5 & 3.7 \\
\hline Free AA N, ${ }^{4} \%$ of total $N$ & 21.9 & 17.9 & 17.5 & 16.0 & 17.5 \\
\hline NAN \% of total N & 95.4 & 96.2 & 96.2 & 96.5 & 96.3 \\
\hline TAAN, $5 \%$ of total $\mathrm{N}$ & 45.5 & 52.4 & 47.6 & 58.9 & 53.5 \\
\hline
\end{tabular}

${ }^{1}$ Provided (per kg of DM): Zn, $56 \mathrm{mg}, \mathrm{Mn}, 46 \mathrm{mg}, \mathrm{Fe}, 22 \mathrm{mg}, \mathrm{Cu}, 12 \mathrm{mg}, \mathrm{I}, 0.9 \mathrm{mg}, \mathrm{Co}, 0.4 \mathrm{mg}$, Se, 0.3 $\mathrm{mg}$, vitamin A, 6440 IU, vitamin D, 2000 IU; and vitamin E, 16 IU.

${ }^{2}$ Computed by discounting dietary energy content based on actual intake (NRC, 2001).

${ }^{3}$ Proportion of total N soluble in 10\% (wt/vol) trichloroacetic acid (Muck, 1987).

${ }^{4}$ Free AA N = total free AA, mmol x (40.3 mg of N/mmol of total free AA) (Broderick, 1987).

${ }^{5}$ Proportion of total $\mathrm{N}$ detected as 17 protein AA in 6-N HCl hydrolysates of each diet.

square) and d 20 (second square), marker infusions were stopped, and samples of whole ruminal contents were taken at 0 (prefeeding), 1, 2, 4, 6, 8, 12 and $24 \mathrm{~h}$ postfeeding. These samples were analyzed for DM, and $\mathrm{Co}$, and $\mathrm{Yb}$ concentrations. Declines in $\mathrm{Co}$ and $\mathrm{Yb}$ concentrations were used to estimate ruminal passage rates of DM in, respectively, fluid and small particle phases. Other specific details regarding this approach, including marker preparation, infusion and analysis, digesta sampling and analysis, and bacterial and protozoal isolation and analysis are described in the companion paper (Reynal et al., 2002).

Whole ruminal contents (100 to $200 \mathrm{ml}$ ) were obtained from all cannulated cows at $0,1,2,4,6,8,12$, and $24 \mathrm{~h}$ after the morning feeding of d 20 of each period, strained through two layers of cheesecloth, and $\mathrm{pH}$ measured immediately. Two subsamples were taken from the resulting strained ruminal fluid: one $10-\mathrm{ml}$ sample was preserved by addition of $0.2 \mathrm{ml}$ of $50 \%$ (vol/vol) $\mathrm{H}_{2} \mathrm{SO}_{4}$ for later analysis of $\mathrm{NH}_{3}$ and total $\mathrm{AA}$, and one 5-ml sample was preserved by the addition of $5 \mathrm{ml}$ of formic acid for later analysis of VFA. Samples for VFA analysis were pooled by mixing equal volumes across times to yield one composite per cow per period. All ruminal samples were stored at $-20^{\circ} \mathrm{C}$. Just before analysis, samples were thawed, centrifuged $(15,000 \times$ $g$ for 15 min at $4{ }^{\circ} \mathrm{C}$ ), and analyzed for $\mathrm{NH}_{3}$ and total free AA (Broderick and Kang, 1980) using flow-injection analysis (Dual-Channel QuikChem 8000 FIA, Lachat Instruments, Milwaukee, WI), and for VFA (Brotz and Schaefer, 1987). Blood samples were taken $4 \mathrm{~h}$ after feeding from the coccygeal artery or vein of each cow on d 17 of each period. Blood was heparinized, held at $4^{\circ} \mathrm{C}$ for $8 \mathrm{~h}$ until plasma was prepared by centrifuging $\left(1,500 \times g, 4^{\circ} \mathrm{C}, 15 \mathrm{~min}\right)$, deproteinized by mixing four volumes of plasma with one volume of $15 \%$ (wt/vol) 5 sulfosalicylic acid, and the supernatant $(15,000 \times g$, $\left.4^{\circ} \mathrm{C}, 15 \mathrm{~min}\right)$ stored at $-20^{\circ} \mathrm{C}$ until analyzed for milk urea $\mathrm{N}$ by a colorimetric assay (Ekinci and Broderick, 1997).

The OTD samples and weekly composites of TMR and feed ingredients were analyzed for total $\mathrm{N}$ (Leco 2000, Leco Instruments, Inc., St. Joseph, MI), DM at $105^{\circ} \mathrm{C}$, ash and $\mathrm{OM}$ (AOAC, 1980), and sequentially for NDF and ADF using heat stable $\alpha$-amylase and $\mathrm{Na}_{2} \mathrm{SO}_{3}$ (Hintz et al., 1995). Extracts also were prepared 
from weekly composites of silages and TMR in distilled water (Muck, 1987). Samples of OTD, TMR extracts, protein supplements, and isolated bacteria were analyzed for $\mathrm{NH}_{3}$ and total free AA as described above for strained ruminal fluid. Extracts from TMR also were analyzed for NPN (Muck, 1987) using a combustion assay (Mitsubishi TN-05 Nitrogen Analyzer; Mitsubishi Chemical Corp., Tokyo). The OTD, bacterial, protozoal samples were analyzed for AA composition using ionexchange chromatography with ninhydrin detection (Beckman 6300 Amino Acid Analyzer, Beckman Instruments, Inc., Palo Alto, CA) after hydrolysis in $6 \mathrm{~N} \mathrm{HCl}$ (Nagel and Broderick, 1992). The methodology used to determine the microbial protein flows, using purines determined by HPLC and spectrophotometry and using linear programming based on AA composition of isolated bacteria and protozoa, is detailed in the companion paper (Reynal et al., 2002). Rate and extent of ruminal protein degradation of protein supplements (SBM, ESBM, BM, and CGM) were estimated using the inhibitor in vitro method (Broderick, 1987). Proportions (\%) and amounts (g/d) of omasal total AA N (TAAN) and NAN flow originating from microbial protein and RUP on all diets were estimated using total purines (determined by both methods) as the microbial marker and computing RUP by difference (Reynal et al., 2002). Except for the protein supplement, the same basal ingredients were fed in basal diet A and other four diets. Therefore, the contribution to RUP flow from the basal ingredients in the protein supplemented diets could be computed based on intake of basal ingredients and applying the proportion of RUP from diet A. The specific details of this approach, including the equations used in these computations, are reported in the companion paper (Reynal et al., 2002).

\section{Statistical Analysis}

Passage rates were estimated by regressing the $\ln$ of $\mathrm{Co}$ and $\mathrm{Yb}$ concentrations on time using a nonlinear method for determining slope (Littell et al., 1996; SAS, 1999); these slopes were equated to the rates of passage (/h) of the DM in the fluid phase (Co) and small particle phase $(\mathrm{Yb})$. Data were analyzed using Proc Mixed in SAS (1999). The following model was fitted to all variables that did not have repeated measurements over time: $\mathrm{Y}_{\mathrm{ijkl}}=\mu+\mathrm{S}_{\mathrm{i}}+\mathrm{P}_{\mathrm{j}}+\mathrm{Vk}_{(\mathrm{i})}+\mathrm{T}_{1}+\mathrm{ST}_{\mathrm{il}}+\mathrm{E}_{\mathrm{ijkl}}$, where $\mathrm{Y}_{\mathrm{ijkl}}=$ dependant variable, $\mu=$ overall mean, $\mathrm{S}_{\mathrm{i}}=$ effect of square $i, P_{j}=$ effect of period $j, V k_{(i)}=$ effect of cow $\mathrm{k}$ (within square $\mathrm{i}$ ), $\mathrm{T}_{1}=$ effect of treatment $1, \mathrm{ST}_{\mathrm{il}}=$ interaction between square $\mathrm{i}$ and treatment $\mathrm{l}$, and $\mathrm{E}_{\mathrm{ijkl}}$ $=$ residual error. All terms were considered fixed, except for $\mathrm{Vk}_{(\mathrm{i})}$ and $\mathrm{E}_{\mathrm{ijkl}}$, which were considered random. The interaction term $\mathrm{ST}_{\mathrm{il}}$ was removed from the model when
$P>0.25$. Differences between least squares means were reported only if the $F$-test for treatment was significant at $\alpha=0.05$. The following model was used for ruminal variables for which there were repeated measurements over time $\left(\mathrm{pH}, \mathrm{NH}_{3}\right.$, total free AA): $\mathrm{Y}_{\mathrm{ijklm}}=\mu+\mathrm{S}_{\mathrm{i}}+\mathrm{P}_{\mathrm{j}}$ $+\mathrm{Vk}_{(\mathrm{i})}+\mathrm{T}_{\mathrm{l}}+\mathrm{ST}_{\mathrm{il}}+\mathrm{E} 1_{\mathrm{ijkl}}+\mathrm{Z}_{\mathrm{m}}+\mathrm{ZT}_{\mathrm{ml}}+\mathrm{E} 2_{\mathrm{ijklm}}$, where $\mathrm{Y}_{\mathrm{ijklm}}=$ dependant variable, $\mu=$ overall mean, $\mathrm{S}_{\mathrm{i}}=$ effect of square $\mathrm{i}, \mathrm{P}_{\mathrm{j}}=$ effect of period $\mathrm{j}, \mathrm{Vk}_{(\mathrm{i})}=$ effect of cow $\mathrm{k}$ (within square $\mathrm{i}$ ), $\mathrm{T}_{1}=$ effect of treatment $1, \mathrm{ST}_{\mathrm{il}}=$ interaction between square $\mathrm{i}$ and treatment $\mathrm{l}$, and $\mathrm{E} 1_{\mathrm{ijkl}}$ = whole plot error, $\mathrm{Z}_{\mathrm{m}}=$ effect of time $\mathrm{m}, \mathrm{ZT}_{\mathrm{ml}}=$ interaction between time $\mathrm{m}$ and treatment 1 , and $\mathrm{E} 2_{\mathrm{ijklm}}=$ subplot error. The spatial covariance structure $\mathrm{SP}(\mathrm{POW})$ was used for estimating covariances and the subject of the repeated measurements were defined as cow(square * period * treatment). All terms were considered fixed, except for $\mathrm{Vk}_{(\mathrm{i})}, \mathrm{E} 1_{\mathrm{ijkl}}$, and $\mathrm{E} 2_{\mathrm{ijklm}}$, which were considered random. The interaction $\mathrm{ST}_{\mathrm{il}}$ was removed from the model when $P>0.25$. Differences between least squares means were reported only if the $F$ test for treatment was significant at $\alpha=0.05$.

\section{RESULTS AND DISCUSSION}

\section{Production and Ruminal Metabolism}

The alfalfa silage contained $36 \% \mathrm{DM}$ and $20.0 \% \mathrm{CP}$ and $39.3 \%$ NDF (DM basis); corn silage contained $37 \%$ $\mathrm{DM}$ and $6.9 \% \mathrm{CP}$ and $40.1 \% \mathrm{NDF}$ (DM basis); and the HMSC contained 73\% DM and 8.3\% CP and 6.7\% NDF (DM basis). Thus, the major feed ingredients were of the high quality typically fed to lactating dairy cows (NRC, 2001). Diets were computed to be isoenergetic, with 1.50 to $1.51 \mathrm{Mcal} \mathrm{NE}_{\mathrm{I}} / \mathrm{kg} \mathrm{DM}$ (NRC, 2001; Table 1). Although originally formulated to contain $17 \% \mathrm{CP}$ in basal diet $\mathrm{A}$ and $21 \% \mathrm{CP}$ in protein supplemented $\operatorname{diets} \mathrm{B}, \mathrm{C}, \mathrm{D}$, and $\mathrm{E}$, the TMR actually fed in this experiment averaged 15.8, 19.1, 19.7, 20.3, and 19.3\% CP for diets A (basal), B (SSBM), C (ESBM), D (BM), and $\mathrm{E}$ (CGM), respectively (Table 1). Because diet A contained less CP and had no added protein concentrate, it contained higher proportions of total $\mathrm{N}$ as NPN, $\mathrm{NH}_{3} \mathrm{~N}$, and total free $\mathrm{AA} \mathrm{N}$ and lower concentrations of individual AA and TAAN, than the other four diets (Table 1). Diet A was formulated to contain large amounts of NPN to minimize the effects on microbial protein formation from RDP supplied by the supplemental proteins added to diets B to E.

Cows fed diet A had mean DMI that was 1.1 to 2.1 $\mathrm{kg} / \mathrm{d}$ lower than cows fed the other $\operatorname{diets}(P<0.05)$; DMI in cows fed diet $\mathrm{C}(\mathrm{ESBM})$ was higher $(P<0.05)$ than that in cows fed diet $\mathrm{D}(\mathrm{BM})$ but not different from cows fed diets B (SSBM) and E (CGM) (Table 2). Broderick et al. (2002) found that supplementing diets containing $60 \%$ hay-crop silage with ESBM increased DMI by 1.3 
Table 2. Effect of feeding protein supplements of differing ruminal degradability on production and ruminal metabolism. ${ }^{1}$

\begin{tabular}{|c|c|c|c|c|c|c|c|}
\hline \multirow{3}{*}{$\begin{array}{l}\text { Item } \\
\text { Protein supplement }\end{array}$} & \multicolumn{5}{|c|}{ Diet } & \multirow[b]{3}{*}{$\mathrm{SE}$} & \multirow[b]{3}{*}{$P>\mathrm{F}^{2}$} \\
\hline & A & $\mathrm{B}$ & $\mathrm{C}$ & D & $\mathrm{E}$ & & \\
\hline & None & SSBM & ESBM & $\mathrm{BM}$ & CGM & & \\
\hline \multicolumn{8}{|l|}{ Production } \\
\hline DMI, kg/d & $21.7^{\mathrm{c}}$ & $23.5^{\mathrm{ab}}$ & $23.8^{\mathrm{a}}$ & $22.8^{\mathrm{b}}$ & $23.7^{\mathrm{ab}}$ & 0.6 & $<0.01$ \\
\hline $\mathrm{OM}$ intake, kg/d & 19.1 & 20.0 & 21.2 & 19.5 & 20.8 & 1.0 & 0.42 \\
\hline $\mathrm{BW}$ gain, $\mathrm{kg} / \mathrm{d}$ & 0.39 & 0.55 & 0.16 & 0.59 & 0.36 & 0.15 & 0.23 \\
\hline Milk yield, $\mathrm{kg} / \mathrm{d}$ & $32.9^{\mathrm{c}}$ & $36.5^{\mathrm{b}}$ & $37.9^{\mathrm{a}}$ & $37.6^{\mathrm{ab}}$ & $38.4^{\mathrm{a}}$ & 1.2 & $<0.01$ \\
\hline $3.5 \% \mathrm{FCM}, \mathrm{kg} / \mathrm{d}$ & $34.8^{\mathrm{b}}$ & $40.0^{\mathrm{a}}$ & $38.4^{\mathrm{a}}$ & $38.3^{\mathrm{a}}$ & $40.5^{\mathrm{a}}$ & 1.3 & $<0.01$ \\
\hline Milk fat, $\%$ & 3.77 & 3.87 & 3.57 & 3.64 & 3.73 & 0.11 & 0.09 \\
\hline Milk fat, $\mathrm{kg} / \mathrm{d}$ & $1.18^{\mathrm{b}}$ & $1.36^{\mathrm{a}}$ & $1.29^{\mathrm{a}}$ & $1.28^{\mathrm{a}}$ & $1.34^{\mathrm{a}}$ & 0.04 & $<0.01$ \\
\hline Milk protein, \% & 3.04 & 3.12 & 3.07 & 3.08 & 3.15 & 0.05 & 0.09 \\
\hline Milk protein, $\mathrm{kg} / \mathrm{d}$ & $0.95^{\mathrm{b}}$ & $1.11^{\mathrm{a}}$ & $1.12^{\mathrm{a}}$ & $1.10^{\mathrm{a}}$ & $1.15^{\mathrm{a}}$ & 0.03 & $<0.01$ \\
\hline $\mathrm{SNF}, \%$ & 8.51 & 8.66 & 8.62 & 8.66 & 8.71 & 0.08 & 0.10 \\
\hline $\mathrm{SNF}, \mathrm{kg} / \mathrm{d}$ & $2.69^{\mathrm{b}}$ & $3.07^{\mathrm{a}}$ & $3.15^{\mathrm{a}}$ & $3.13^{\mathrm{a}}$ & $3.18^{\mathrm{a}}$ & 0.1 & $<0.01$ \\
\hline Blood urea $\mathrm{N}, \mathrm{m} M$ & $8.97^{\mathrm{b}}$ & $9.78^{\mathrm{a}}$ & $9.75^{\mathrm{a}}$ & $9.73^{\mathrm{a}}$ & $9.75^{\mathrm{a}}$ & 0.09 & $<0.01$ \\
\hline \multicolumn{8}{|c|}{ Apparent total tract digestibility } \\
\hline $\mathrm{DM}, \%$ & $69.0^{\mathrm{c}}$ & $73.1^{\mathrm{a}}$ & $69.1^{\mathrm{c}}$ & $69.7^{\mathrm{bc}}$ & $71.6^{\mathrm{ab}}$ & 0.8 & $<0.01$ \\
\hline NDF, $\%$ & $40.9^{\mathrm{c}}$ & $48.2^{\mathrm{a}}$ & $43.6^{\mathrm{bc}}$ & $45.8^{\mathrm{ab}}$ & $43.8^{\mathrm{bc}}$ & 1.2 & $<0.01$ \\
\hline $\mathrm{ADF}, \%$ & $42.1^{\mathrm{c}}$ & $49.1^{\mathrm{a}}$ & $43.8^{\mathrm{bc}}$ & $46.6^{\mathrm{ab}}$ & $44.4^{\mathrm{bc}}$ & 1.2 & $<0.01$ \\
\hline \multicolumn{8}{|l|}{ Ruminal metabolism } \\
\hline $\mathrm{pH}$ & 6.18 & 6.09 & 6.16 & 6.00 & 6.16 & 0.06 & 0.07 \\
\hline Total AA, mM & 3.11 & 3.47 & 2.98 & 3.20 & 2.81 & 0.23 & 0.15 \\
\hline $\mathrm{NH}_{3}, \mathrm{~m} M$ & $8.01^{\mathrm{d}}$ & $11.24^{\mathrm{a}}$ & $10.35^{\mathrm{ab}}$ & $9.94^{\mathrm{bc}}$ & $9.09^{\mathrm{cd}}$ & 0.42 & $<0.01$ \\
\hline Total VFA, mM & $110.2^{\mathrm{b}}$ & $119.2^{\mathrm{a}}$ & $114.9^{\mathrm{ab}}$ & $119.0^{\mathrm{a}}$ & $112.4^{\mathrm{b}}$ & 2.7 & $<0.01$ \\
\hline Acetate, $\mathrm{m} M$ & $68.8^{\mathrm{b}}$ & $74.2^{\mathrm{a}}$ & $72.6^{\mathrm{a}}$ & $73.9^{\mathrm{a}}$ & $71.3^{\mathrm{ab}}$ & 1.4 & 0.02 \\
\hline Propionate, $\mathrm{m} M$ & $22.6^{\mathrm{b}}$ & $24.6^{\mathrm{ab}}$ & $23.1^{b}$ & $25.7^{\mathrm{a}}$ & $22.2^{\mathrm{b}}$ & 1.3 & 0.03 \\
\hline $\mathrm{A}: \mathrm{P}$ ratio & 3.15 & 3.05 & 3.18 & 2.96 & 3.31 & 0.15 & 0.11 \\
\hline Butyrate, $\mathrm{m} M$ & 13.7 & 14.7 & 13.7 & 14.2 & 13.1 & 0.5 & 0.24 \\
\hline Isobutyrate, $\mathrm{m} M$ & $1.11^{\mathrm{d}}$ & $1.31^{\mathrm{a}}$ & $1.25^{\mathrm{ab}}$ & $1.13^{\mathrm{cd}}$ & $1.21^{\mathrm{bc}}$ & 0.03 & $<0.01$ \\
\hline \multicolumn{8}{|l|}{ Isovalerate + } \\
\hline 2-methyl butyrate, $\mathrm{m} M$ & 2.01 & 2.28 & 2.17 & 2.15 & 2.30 & 0.10 & 0.11 \\
\hline Valerate, $\mathrm{m} M$ & 2.01 & 2.10 & 2.04 & 2.03 & 2.17 & 0.16 & 0.73 \\
\hline
\end{tabular}

$\mathrm{kg} / \mathrm{d}$. Daily BW gain was not different among diets. However, cows fed basal diet A had the lowest yields of milk, FCM, fat, protein, and SNF, probably as a result of having the lowest DMI (Table 2). Cows fed diets $\mathrm{C}(\mathrm{ESBM})$ and $\mathrm{E}(\mathrm{CGM})$ produced 1.4 and $1.9 \mathrm{~kg} /$ $\mathrm{d}$ more milk than cows fed diet B (SSBM). Broderick et al. (1990) observed a 1-kg/d increase in milk yield in cows fed ESBM and similar milk yield on ESBM and CGM relative to feeding SSBM when alfalfa silage was the only forage and DMI averaged $24 \mathrm{~kg} / \mathrm{d}$. Berzaghi and Polan (1991) reported $0.9 \mathrm{~kg} / \mathrm{d}$ greater milk yield when cows fed diets based on alfalfa silage were supplemented with CGM instead of SSBM. Milk yield of cows fed diet D, that supplemented with BM, was intermediate; however, DMI was numerically lowest on BM of the four protein-supplemented diets. Yields of fat, protein, and SNF were not different among diets B, C, D, and E. Although milk yield was affected by protein source, FCM yield was not. This may be explained by the numerical differences $(P=0.09)$ in milk fat concen- tration among diets B to E. Compared to cows fed diets $\mathrm{C}$ and $\mathrm{E}$, cows fed diet B produced less milk but with numerically higher fat concentration, resulting in similar yields of FCM. Milk concentrations of fat, protein, and SNF were unaltered by diet.

Neither ruminal $\mathrm{pH}$ nor total free AA concentrations were affected by diet (Table 2). However, ruminal $\mathrm{NH}_{3}$ concentrations were substantially different. Basal diet $\mathrm{A}$ and diet $\mathrm{E}$ (CGM) gave rise to the lowest, and diet $\mathrm{B}$ (SSBM) the highest, $\mathrm{NH}_{3}$ in the rumen; ruminal $\mathrm{NH}_{3}$ was intermediate on diets $\mathrm{C}(\mathrm{ESBM})$ and $\mathrm{D}(\mathrm{BM})$. Lower $\mathrm{CP}$ and higher HMSC, which could have enhanced microbial NPN utilization, may account for reduced $\mathrm{NH}_{3}$ concentrations on diet A. Blood urea concentration also was affected by diet $(P<0.01)$ with that on diet A being lowest. However, ruminal $\mathrm{NH}_{3}$ was not well correlated with blood urea across diets. The relationship of ruminal $\mathrm{NH}_{3}$ to protein degradation will be discussed below. Cows fed diets $\mathrm{B}$ and $\mathrm{D}$ had higher ruminal concentrations of total VFA than cows fed $\operatorname{diets} \mathrm{A}$ and $\mathrm{E}(P<$ 
0.05), with cows fed diet $\mathrm{C}$ being intermediate (Table 2). Ruminal VFA concentrations are the net result of production and absorption and do not necessarily reflect fermentation rates (Dijkstra et al., 1993). Moreover, the range of total VFA concentrations was narrow from only 110 to $119 \mathrm{mM}$, and these small changes may not have been biologically important. Acetate concentration was lower in cows fed diet A than cows fed diets B, C, and $\mathrm{D}$ but not different from that on diet $\mathrm{E}$. Ruminal propionate was higher on diet $\mathrm{D}$ than on all other diets except B. However, dietary effects on ruminal acetate and propionate concentrations were small, and there were no significant differences in acetate:propionate ratios. Although ruminal butyrate, isovalerate plus 2methyl butyrate, and valerate were not affected by diet, cows fed diet B (SSBM) had higher isobutyrate than cows fed basal diet $\mathrm{A}$ and diets $\mathrm{D}(\mathrm{BM})$ and $\mathrm{E}(\mathrm{CGM})$; isobutyrate was intermediate on diet C (ESBM). The branched-chain VFA, isobutyrate, isovalerate, and 2methyl butyrate originate from ruminal catabolism of branched-chain AA and are important growth factors for cellulolytic bacteria (Hoover, 1986). Lower isobutyrate concentrations on diets $\mathrm{A}$ and $\mathrm{D}$ may have reflected smaller amounts of true protein degradation in the rumen on the basal diet and from BM. However, there were no dietary effects on isovalerate plus 2-methyl butyrate, which represented about twice the proportion of degraded AA as isobutyrate, suggesting that branched-chain VFA were not a sensitive indicator of ruminal protein degradation in this experiment.

Neither ruminal OM and NDF digestibilities nor ruminal passage rates of the large particle and small particle pools were altered by diet (Table 3). However, the similarity of the passage rates for the fluid (Co-EDTA mean $=0.14 / \mathrm{h})$ and small particle phases $(\mathrm{Yb}=0.13 / \mathrm{h})$ was surprising. Hristov and Broderick (1996) reported mean liquid and particle passage rates of 0.16 and $0.05 /$ $\mathrm{h}$ in cows with DMI of $17 \mathrm{~kg} / \mathrm{d}$, but they estimated particulate passage rates using $\mathrm{Yb}$ adsorbed onto feed material retained on a screen with 1.15 -mm pores. Infusing $\mathrm{Yb}$ directly into the rumen probably results in preferential attachment onto small particles that may pass from the rumen more rapidly. Siddons et al. (1985) reported that in sheep continuously infused with $\mathrm{Yb}$ acetate into the rumen $>90 \%$ of the $\mathrm{Yb}$ in rumen, duodenal, and ileal digesta was associated with particulate matter; however, the $\mathrm{Yb}$ was not uniformly distributed and $\mathrm{Yb}$ concentration per unit DM increased as particle size decreased. Smaller feed particles have shorter mean retention times than larger particles, although small particles still do not pass out of the rumen as rapidly as the liquid phase (Cherney et al., 1991). Generally, apparent total tract digestibility was greatest on the diet B (SSBM): digestibility of DM, NDF, and
$\mathrm{ADF}$ on this diet was higher than on diets A (basal) and $\mathrm{C}$ (ESBM). Also, digestibility of DM was higher on $\operatorname{diet} \mathrm{B}$ than diet $\mathrm{D}$, and digestibility of both NDF and $\mathrm{ADF}$ was higher on diet $\mathrm{B}$ than on $\operatorname{diet} \mathrm{E}$. This suggests that replacing HMSC with DM, and especially nonforage fiber, from SSBM increased total tract digestibility.

\section{Omasal Nutrient Flows}

There were no effects of diet on flows of DM, OM, ADIN, $\mathrm{NH}_{3}-\mathrm{N}$, or free AA-N at the omasal canal (Table 3 ). However, omasal flows of total $\mathrm{N}$ and NAN were greater on the four protein-supplemented diets than on $\operatorname{diet}$ A. Although both fractions are representative of true protein, there were greater differences due to diet in omasal TAAN flow than in NAN flow: again $\operatorname{diet}$ A was lowest, but TAAN flow was higher for diet D (BM) than for diet B (SSBM), with TAAN flows for diets C (ESBM) and E (CGM) being intermediate. Waltz et al. (1989) reported that cows supplemented with BM had lower TAAN intake but similar TAAN flow to the duodenum when compared to cows supplemented with SSBM. Had DMI been equal in the Waltz et al. (1989) trial, BM may have increased the supply of TAAN to the small intestine. The flow of NAN was lowest for $\operatorname{diet} A$ but was not significantly different among diets B to E. In a literature review, Santos et al. (1998) summarized 24 trials where high RUP sources replaced SSBM in the diet and found that NAN flows to the small intestine were increased in only five of these trials. They also reported that the lack of an increase in total NAN flow when high RUP sources replaced SSBM occurred because decreased microbial $\mathrm{N}$ flow approximately compensated for increased flow of dietary NAN. In our experiment, although not significantly different $(P=0.08)$, bacterial NAN flows to the omasum were numerically lower for BM and CGM than for SSBM and ESBM using estimates based on linear programming (Reynal et al., 2002). Lower microbial NAN flow could have counterbalanced any increased dietary NAN flow in cows fed $\mathrm{BM}$ and CGM. Interestingly, milk protein yield-which increased with protein supplementation but was not different among the four protein containing diets (Table 2)-reflected the pattern of omasal NAN flow rather than that of TAAN flow. That greater omasal TAAN flow due to greater ruminal BM escape did not give rise to greater protein yield than when SSBM was fed may have been related to differences between these two proteins in RUP digestibility. The NRC (2001) assigned intestinal digestibilities of 93 and $80 \%$ for the RUP fractions of SSBM and BM, respectively.

\section{Rates of Protein Degradation}

Estimates of extent of ruminal escape of the four protein supplements based on omasal TAAN or NAN 
Table 3. Effect of feeding protein supplements of differing ruminal degradability on ruminal digestion and passage rate and on omasal nutrient flows. ${ }^{1}$

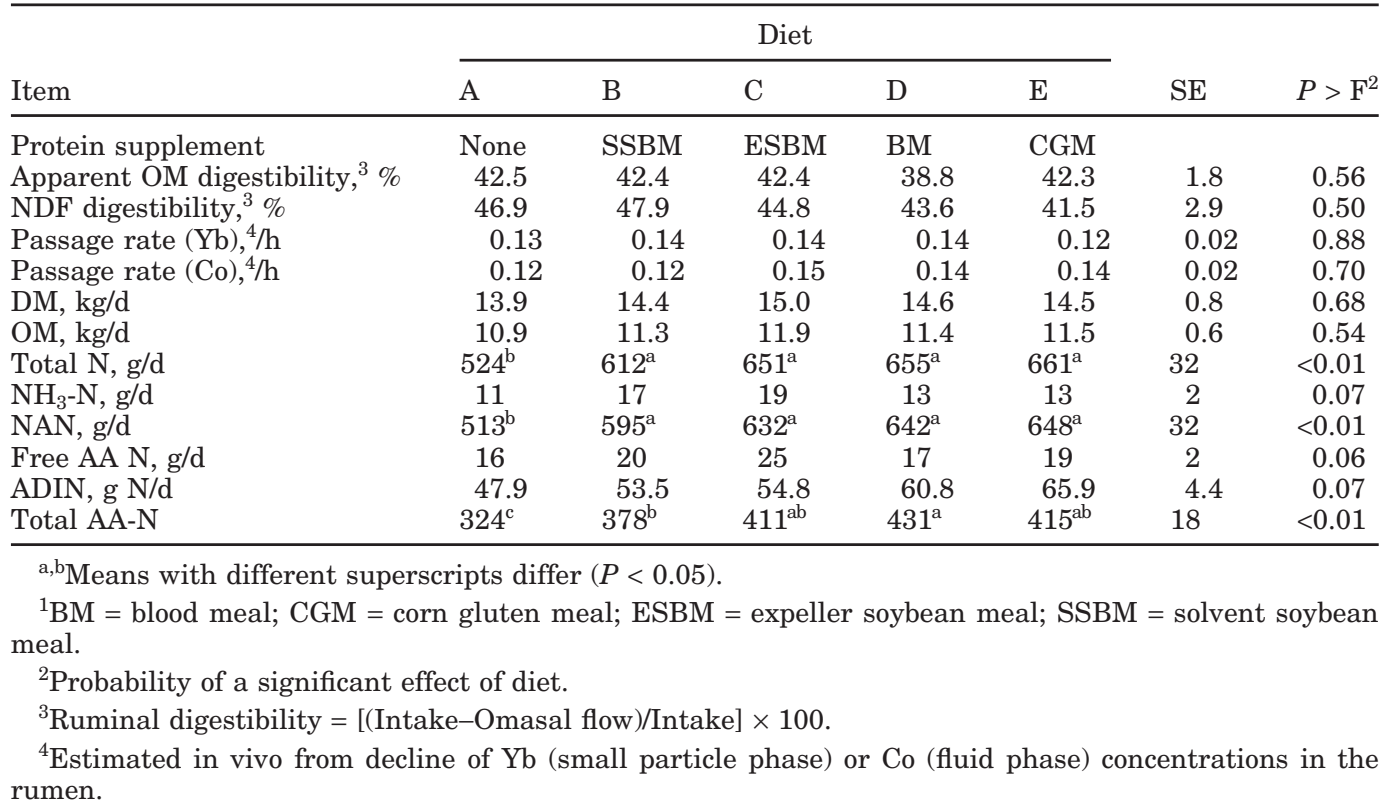

flows were computed using results from both spectrophotometric and HPLC methods for purine determination (Reynal et al., 2002). Mean ruminal escapes for SSBM, ESBM, BM, and CGM were, respectively, 27, 45,60 , and $73 \%$ (Table 4). A major objective of our study was to determine in vivo ruminal degradation rates of the four supplemental proteins. Extent of protein degradation is the resultant of the rates of passage and degradation, and both must be known to estimate the amount of protein escaping rumen degradation for a given feeding situation. In our study, rates of passage of fluid and small particle phases were estimated using $\mathrm{Co}$ and $\mathrm{Yb}$, respectively. Particle size of the protein concentrates was such that they would have been expected to pass with the small particle phase; however, passage rates estimated using $\mathrm{Yb}$ and Co were nearly identical (Table 3). The NPN (fraction A) and ADIN (fraction $\mathrm{C}$ ) contents were small, and the proportions of degradable protein (fraction B) ranged from 92.6 to $98.5 \%$ for the four proteins (Table 4). In vivo degradation rates for the fractions $\mathrm{B}$ were computed using the passage rates observed for small particles (mean $\mathrm{Yb}$ rate $=0.14 / \mathrm{h}$ ), and assuming a passage rate of $0.06 / \mathrm{h}$, based on TAAN and NAN flows from both purine assays. A discount for the small amount of fraction $\mathrm{C}$ in each protein supplement also was included in the computation. Mean rates of ruminal protein degradation for SSBM, ESBM, BM, and CGM were, respectively, 0.417, 0.179, 0.098, and 0.051/h (small particle passage rates), and $0.179,0.077,0.042$, and $0.026 / \mathrm{h}$ (passage rate $=0.06 / \mathrm{h}$ ). Rates computed using TAAN data tended to be more rapid than those computed using NAN flows (Table 4), and these differences were substantially influenced by the proportions of RUP estimated for basal ingredients from flow of TAAN $(30 \%)$ and NAN (20\%) on basal diet A (Reynal et al., 2002). Values based on TAAN flow likely were less affected by the behavior of non-AA $\mathrm{N}$ that may escape the rumen but would not contribute to the AA nutrition of the animal.

Rates computed using the small particle passage rates (Table 4) ranged from 2.5-times (SSBM) to about 10-times (BM) more rapid than those determined using the IIV method (Broderick, 1987). The degradation rate computed for SSBM using the $0.06 / \mathrm{h}$ passage rate was more similar to that determined by IIV. However, although slower, degradation rates computed for ESBM, $\mathrm{BM}$, and CGM, using the $0.06 / \mathrm{h}$ passage rate, were still two, four, and three times more rapid than those determined by IIV. Previously, we saw very slow IIV degradation rates in all but two of $81 \mathrm{BM}$ samples; the two exceptions were BM that were completely buffer soluble and appeared to be processed without heating (G. A. Broderick, unpublished data). Earlier, we observed an IIV degradation rate of $0.02 / \mathrm{h}$ for a sample of CGM (Broderick et al., 1990). That milk yields were not different with feeding of ESBM, BM, or CGM (Table 2 ) suggested that the IIV degradation rates were too slow for both BM and CGM. The relative in vivo degradation rates, estimated using either small particle passage rates or an assumed rate of $0.06 / \mathrm{h}$, should make 
Table 4. Rate and extent of ruminal degradation of protein supplements estimated in vitro and in vivo. ${ }^{1}$

\begin{tabular}{|c|c|c|c|c|}
\hline \multirow[b]{2}{*}{ Item } & \multicolumn{4}{|c|}{ Protein supplement } \\
\hline & SSBM & ESBM & $\mathrm{BM}$ & CGM \\
\hline Fraction A (NPN), \% total N & 1.2 & 0.9 & 0.3 & 1.0 \\
\hline Fraction $\mathrm{B}, \%$ total $\mathrm{N}$ & 96.8 & 96.8 & 98.5 & 92.6 \\
\hline Fraction $\mathrm{C}(\mathrm{ADIN}), \%$ total $\mathrm{N}$ & 2.0 & 2.3 & 1.2 & 6.4 \\
\hline \multicolumn{5}{|l|}{ In vitro results ${ }^{2}$} \\
\hline Ruminal degradation rate, $/ \mathrm{h}$ & 0.17 & 0.04 & 0.01 & 0.01 \\
\hline RUP, \% of total CP & 26 & 58 & 85 & 86 \\
\hline \multicolumn{5}{|l|}{ In vivo results } \\
\hline Passage rate $\left(\mathrm{Yb}-\mathrm{k}_{\mathrm{SP}}\right),{ }^{3} / \mathrm{h}$ & 0.14 & 0.14 & 0.14 & 0.12 \\
\hline RUP $_{\text {Protein }}(\mathrm{TAAN}),{ }^{4} \%$ & 29 & 44 & 56 & 60 \\
\hline $\mathrm{RUP}_{\text {Protein }}(\mathrm{NAN}){ }^{4} \%$ & 36 & 40 & 69 & 76 \\
\hline RUP Protein $(\mathrm{TAAN}),{ }^{5} \%$ & 21 & 48 & 52 & 67 \\
\hline $\mathrm{RUP}_{\text {Protein }}(\mathrm{NAN}),{ }^{5} \%$ & 24 & 48 & 63 & 89 \\
\hline Mean RUP Protein $\%$ & 27 & 45 & 60 & 73 \\
\hline SD & 6 & 4 & 7 & 13 \\
\hline \multicolumn{5}{|l|}{ Ruminal degradation rate } \\
\hline Mean $\left(\mathrm{Yb}-\mathrm{k}_{\mathrm{SP}}\right),{ }^{6} / \mathrm{h}$ & 0.417 & 0.179 & 0.098 & 0.051 \\
\hline SD & 0.131 & 0.028 & 0.029 & 0.031 \\
\hline \multicolumn{5}{|l|}{ Ruminal degradation rate } \\
\hline Mean $\left(\mathrm{k}_{\mathrm{p}}=0.06 / \mathrm{h}\right),{ }^{6} / \mathrm{h}$ & 0.179 & 0.077 & 0.042 & 0.026 \\
\hline SD & 0.056 & 0.012 & 0.012 & 0.016 \\
\hline
\end{tabular}

\footnotetext{
${ }^{1} \mathrm{BM}=$ blood meal; $\mathrm{CGM}$ = corn gluten meal; ESBM = expeller soybean meal; $\mathrm{SSBM}$ = solvent soybean meal; TAAN = total AA N.

${ }^{2}$ Estimated in vitro, assuming a ruminal passage rate of 0.06/h (Broderick, 1987).

${ }^{3}$ In vivo ruminal $\mathrm{Yb}$ (small particle) passage rate (Table 2).

${ }^{4}$ Determined in vivo from RUP Protein (TAAN) and RUP Protein $_{\text {(NAN) flows estimated using the HPLC purine }}$ method to quantify microbial TAAN and NAN flows (Table 5, Reynal et al., 2002).

${ }^{5}$ Determined in vivo from RUP $P_{\text {Protein }}(T A A N)$ and RUP $P_{\text {Protein }}(N A N)$ flows estimated using the spectrophotometric total purine method to quantify microbial TAAN and NAN flows (Table 5, Reynal et al., 2002).

${ }^{6}$ In vivo ruminal degradation rate $=\left[\left(\right.\right.$ fraction $\left.\mathrm{B} \times \mathrm{k}_{\mathrm{p}}\right) /(\mathrm{RUP}-$ fraction $\left.\mathrm{C})\right]-\mathrm{k}_{\mathrm{p}}$, where $\mathrm{k}_{\mathrm{p}}$ was either the ruminal $\mathrm{Yb}$ passage rate or assumed to equal $0.06 / \mathrm{h}$.
}

these proteins useful standards for comparison with in situ results and for development of in vitro methods.

\section{SUMMARY}

In vivo ruminal degradability of SSBM, ESBM, BM, and CGM was assessed in lactating dairy cows from relative production and by measuring omasal TAAN and NAN flows in ruminally cannulated animals. Isonitrogenous amounts of each protein were added to a high NPN basal diet at the expense of HMSC. Responses of DMI and yields of milk, fat, protein, and SNF with supplemental protein indicated the basal diet supplied inadequate amounts of absorbable protein. Among supplemented diets, milk yield was greatest on ESBM and CGM, least on SSBM, and intermediate on BM. Rates of degradation for the four proteins, estimated using two different methods of purine determination to quantify microbial protein flow and computed using passage rates observed for the small particle phase, were more rapid than rates reported in the literature. Degradation rates computed assuming a passage rate of $0.06 / \mathrm{h}$ were more rapid than rates determined using the IIV method. These four experimental proteins will serve as standards for development of in vitro methods for predicting rates of ruminal protein degradation.

\section{ACKNOWLEDGMENTS}

The authors thank Rick Walgenbach and the farm crew for harvesting and storing the feeds and Len Strozinski and the barn crew for animal care and sampling at the US Dairy Forage Center Research Farm (Prairie du Sac, WI); Ignacio Echagüe and Agustina Sabalzagaray for helping with sampling at the farm and with laboratory analyses; Brad Ricker, Mary Becker, and Wendy Radloff for conducting laboratory analyses; Ron Hatfield for assisting with HPLC analyses; and Peter Crump for assisting with statistical analyses.

\section{REFERENCES}

Agricultural and Food Research Council. 1992. Nutrient Requirements of Ruminant Animals: Protein. Technical Committee on Responses to Nutrients. Report No. 9. Nutr. Abstr. Rev. (Ser. B) 62:787-835.

Association of Official Analytical Chemists. 1980. Official Methods of Analysis. 13th ed. AOAC, Washington, DC.

Ahvenjarvi, S., A. Vanhatalo, P. Huhtanen, and T. Varvikko. 2000. Determination of reticulo-rumen and whole-stomach digestion in 
lactating cows by omasal canal or duodenal sampling. Br. J. Nutr. 83:67-77.

Berzaghi, P., and C. E. Polan. 1991. Effect of undegradable protein on milk production and milk composition when cows were fed alfalfa haylage based diets. J. Dairy Sci. 74(Suppl.1):216, (Abstr.)

Broderick, G. A., and J. H. Kang. 1980. Automated simultaneous determination of ammonia and total amino acids in ruminal fluid and in vitro media. J. Dairy Sci. 63:64-75.

Broderick, G. A. 1987. Determination of protein degradation rates using a rumen in vitro system containing inhibitors of microbial nitrogen metabolism. Br. J. Nutr. 58:463-476.

Broderick, G. A., D. B. Ricker, and L. S. Driver. 1990. Expeller soybean meal and corn by-products versus solvent soybean meal for lactating dairy cows fed alfalfa silage as sole forage. J. Dairy Sci. 73:453-462.

Broderick, G. A., D. R. Mertens, and R. Simons. 2002. Efficacy of carbohydrate sources for milk production by cows fed diets based on alfalfa silage. J. Dairy Sci. 85:1767-1776.

Broderick, G. A. 1994. Quantifying forage protein quality. Pages 200 238 in G. C. Fahey, Jr., M. D. Collins, D. R. Mertens, and L. E. Moser ed. Forage Quality, Evaluation and Utilization. American Soc. Agron., Madison, WI

Brotz, P. G., and D. M. Schaefer. 1987. Simultaneous determination of lactic acid and volatile fatty acids in microbial fermentation extracts by gas-liquid chromatography. J. Microbiol. Methods $6: 139-144$

Cherney, D. J. R., D. R. Mertens, and J. E. Moore. 1991. Fluid and particulate retention times in sheep as influenced by intake level and forage morphological composition. J. Anim. Sci. 69:413-422.

Dijkstra, J., H. Boer, J. Van-Bruchem, M. Bruining, and S. Tamminga. 1993. Absorption of volatile fatty acids from the rumen of lactating dairy cows as influenced by volatile fatty acid concentration, $\mathrm{pH}$ and rumen liquid volume. Brit. J. Nutr. 69:385-396.

Ekinci, C. and G. A. Broderick. 1997. Effect of processing high moisture ear corn on ruminal fermentation and milk yield. J. Dairy Sci. 80:3298-3307.

France, J., and R. C. Siddons. 1986. Determination of digesta flow by continuous marker infusion. J. Theor. Biol. 121:105-119.

Hoover, W. H. 1986. Chemical factors involved in ruminal fiber digestion. J. Dairy Sci. 69:2755-2766.

Hintz, R. W., D. R. Mertens, and K. A. Albrecht. 1995. Effects of sodium sulfite on recovery and composition of detergent fiber and lignin. J. A. O. A. C. 78:16-22.
Hristov, A. N., and G. A. Broderick. 1996. Synthesis of microbial protein in ruminally cannulated cows fed alfalfa silage, alfalfa hay, or corn silage. J. Dairy Sci. 79:1627-1637.

Huhtanen, P., P. G. Brotz, and L. D. Satter. 1997. Omasal sampling technique for assessing fermentative digestion in the forestomach of dairy cows. J. Animal Sci. 75:1380-1392.

Huhtanen, P., K. Kaustell, and S. Jaakkola. 1994. The use of internal markers to predict total digestibility and duodenal flow of nutrients in cattle given six different diets. Anim. Feed Sci. Tech. 48: 211-227.

Littell, R. C., G. A. Milliken, W. W. Stroup, and R. D. Wolfinger. 1996. SAS System for Mixed Models. SAS Inst., Inc., Cary, NC.

Muck, R. E. 1987. Dry matter level effects on alfalfa silage quality. 1. Nitrogen transformations. Trans. ASAE (Am. Soc. Agric. Eng.) 30:7-14

Nagel, S. A. and G. A. Broderick. 1992. Effect of formic acid or formaldehyde treatment of alfalfa silage on nutrient utilization by dairy cows. J. Dairy Sci. 75:140-154.

National Research Council. 2001. Nutrient Requirements of Dairy Cattle. 7th rev. ed. Nat. Acad. Sci. Washington, DC.

Reynal, S., G. A. Broderick, S. Ahvenjarvi, and P. Huhtanen. 2002. Effect of feeding protein supplements of differing degradability on omasal flow of microbial and undegraded protein. J. Dairy Sci. 85: submitted.

Santos, F. A. P., J. E. P. Santos, C. B. Theurer, and J. T. Huber 1998. Effects of rumen-undegradable protein on dairy cow performance: A 12-year literature review. J. Dairy Sci. 81:3182-3213.

SAS. 1999-2000. SAS/STAT User's Guide (Release 8.1), SAS Inst., Inc., Cary, NC.

Siddons, R. C., J. Paradine, D. E. Beever, and P. R. Cornell. 1985. Ytterbium acetate as a particulate-phase digesta-flow marker. Br. J. Nutr. 54:509-519.

Sniffen, C. J., J. D. O'Connor, P. J. van Soest, D. G. Fox, and J. B. Russell. 1992. A net carbohydrate and protein system for evaluating cattle diets. II. Carbohydrate and protein availability. J. Anim. Sci. 70:3562-3577.

Uden, P., P. E. Colucci, and P. J. van Soest. 1980. Investigation of chromium, cerium and cobalt as markers in digesta. Rate of passage studies. J. Sci. Food Agric. 31:625-632.

Waltz, D. M., M. D. Stern, and D. J. Illg. 1989. Effect of ruminal protein degradation of blood meal and feather meal on the intestinal amino acid supply to lactating cows. J. Dairy Sci. 72:15091518 